\title{
Government, Democracy and Dysfunctional Governance in Nigeria
}

\author{
Abah, Emmanuel O. Ph.D ${ }^{1}$, Ibeogu, Aloysius S. ${ }^{2}$ \\ ${ }^{1,2}$ Department of Public Administration Ebonyi State University, Abakaliki
}

\begin{abstract}
This study is a critical analysis of Nigerian democratic experiment and crisis of governance. It is axiomatic to state that Nigeria is naturally endowed with both human and material resources that can trigger off national development and growth but still grope with unbridled failures, weak economy and high debt profile. The main reasons for the undemocratic practice and socio economic stagnation are the leadership crises; bad policies, poor moral and ethical standards, undemocratic selection process (imposition pattern), political corruption which have weakened the system of governance. The study focused to establish how the governors of Nigerian States handled the affairs of the people they govern and reasons for the underdevelopment especially in the rural areas. The study adopted elite and anomic theories considered relevant to this study as theoretical framework of analysis. The study established that; selection and imposition of candidates as our leaders, corruption of the democratic and electoral system by the ruling class have contributed in negating good governance and enthroning callousness among our elected leaders. The implication of the study is that if these ugly trends among our leaders are not checked especially at the state level, it could lead to lawlessness, mass poverty and sacrifice of moral rectitude at the altar of hooliganisms among the people. Recommendations were made that the government should be more sensitive to the plight of her citizens, by way of creating employment opportunities for the teaming unemployed youths, sustaining the payment of worker's salaries and provision of social amenities that will bring about improved living condition of the people.
\end{abstract}

Keywords: Nigerian Government, Democracy, Economy, Dysfunctional Governance.

\section{INTRODUCTION}

Leadership is at the top of most experiential realities but often neglected phenomena globally. As aptly stated by Ijewereme (2014), "the extent of development of any nation globally is often been determined by the quality and selfless nature of its leaders". Effective leadership guarantees the right to choose the leaders and enthrone peace, harmony, justice and progress. Edwinah (2014) asserts that to ensure sustainable development, sustainable peace must be put in place. To ensure peace and progress, security is vital in any society. Security ensures peace of mind and the possibility to sleep well. Security implies stability and continuity, but insecurity has become a topical issue in today Nigeria's democratic discourse. Insecurity (vulnerability) implies the inability to cope with shock or misfortune. Increase in insecurity and vulnerability results in pervasive anxiety, fear and anger. On October $1^{\text {st }} 1960$, Nigeria secured political independence from her former colonial masters. The citizens were overjoyed and proud at the very idea of being free at last, hence we could manage our own affairs in our father land.The euphoria that gripped every Nigerian on the occasion of that historical event found vivid expression in the independence message of Sir Alhaji Abubakar Tafawa Balewa, the then Prime Minister, who had the privilege of receiving the constitutional instrument of self-rule to Nigeria. He said: "this is a wonderful day and it is all the more wonderful because we have awaited with increasing impatience, compelled to watch one country after another overtaking us on the road when we have so nearly reached our goal, but now we have acquired our right status and I feel sure that history will show that the building of our nation proceeded the wisest pace. It has been through, and Nigeria now stands well built upon firm foundations" (Odey, 2015). In the same ecstasy, the same prime minister later declared: "Fellow Nigerians, here we go. We are going to the moon and even the great galaxies beyond" (Odey, 2015). He was sure that Nigeria had not only been born, it had really and truly arrived on the arena of the comity of nations that would make amazing history in an age of scientific and technological wonders. In his own inaugural speech as the first President of Nigeria, Dr. Nnamdi Azikiwe equally expressed the satisfaction that filled the hearts of Nigerians when he said; "As for me, my stiffest earthily assignment is ended and my major life's work is done. My country is now free, and has been honoured to its first indigenous head of state. I thank God for sparing my life to witness the independence of my native land" (Odey, 2015). Many years after,wherever these nationalists are, if there were given the privilege to watch what goes on here in Nigeria, the country they sweated and suffered to set free from colonial bondage, (Tafawa Balewa, Nnamdi Azikiwe, Obefemi Awolowo) and many others whose sacrifice made Nigerians political independence a reality would be twitching in utter restlessness and discomfort because their dream for 
a better Nigeria has been turned into a nightmare by the misdeeds of those who succeeded them and became pirates in power. On January $15^{\text {th }}$, 1966, barely five years and three months after the founding fathers of Nigeria assured us that the attainment of political independence had opened Nigeria's express way to the great galaxies; a section of the army revolted and threw out the government of the first republic (1960 - 1966). In a nationwide broadcast, Major Chukwuma Kaduna Nzeogwu, the leader of the coup said; "The constitution is suspended and the regional government and elected assemblies are hereby dissolved. All political, cultural, tribal and trade union activities, together with all demonstrations and unauthorized gatherings, religions worships are banned until further notice" (Odey, 2015).

The following day, January $16^{\text {th }} 1966$, Major General J.T.U Aguiyi-Ironsi, addressed the nation, confirming the military coup. He said: "The government of the federation of Nigeria having ceased to function, the Nigeria Armed Forces have been invited to form an Interim Military Government for the purpose of maintaining law and order, and of maintaining essential services.(Odey, 2015). On October $1^{\text {st }} 1985$, at a time that Nigeria clocked $25 \mathrm{yrs}$ as an independent country, the editorial comment of the National Concord newspaper, with the caption, "A Solemn Jubilee", described the political history of Nigeria as "an undulating landscape of brave ambitions and cataclysmic failures: a chronicle of the enduring struggle between a nation's lofty dreams and it's harsh, unyielding realities: the heart - breaking saga of a people whose material trajectory has made the full circle from privation to affluence and then again to privation".

In October 1994, late Chief Gani Fawehinmi felt that Nigeria was at the crossroads as a result of the misdeeds of those who pilot her affairs, he lamented. "The legacy of both the military and civilian administrations is a legion of looting of the nation's resources and shameless flaunting of the loot by leaders, their cohorts and stooges; the animated decimation of our social life, the organized destruction of our economy; the brutal repression of our fundamental rights; the castration of our democratic institutions; the dehumanization of our national psyche; the planned and systematic devastation of our national infrastructure of all categories; the corrosive pollution of our moral life; the ungodly contamination of our national values; the imposition of pervasive, grinding, heinous and aching poverty on the masses of our people. These constitute the political and socio - economic disorder of today (Odey, 2015). We are all familiar with plain historical fact that every nation has within itself the political seeds of both glorious rise and degrading downfall. These two extreme opposites are ever in a dialectical conflict, where each one vies for predominance over the other. In between them, are the people that make up the society, and whichever of the two opposite they choose to harness, that will prevail over the other, shape the people's philosophy of life and moral values and then determine how they will live and behave. Nigeria is fifty -seven years (57yrs) old as an independent country. While we have many things for which to thank God for in our country, it can be admitted that the undulating landscape of brave ambitions and cataclysmic failures that the National Concord Newspaper talked about thirty two years (32yrs) ago, and the political and socio - economic disorder brought about by the greed, selfishness, and lack of vision on the part of our leaders as recounted by Gani , as stated above,twenty -three years (23yrs) ago have combined to take a leap into a more dangerous zone, and transformed into political, ethnic and religious monsters that have currently turned Nigeria into a state of blood.

Fifty-seven years (57yrs) after political independence, Nigeria is still floating in the air like an aircraft whose pilot has been mystified by a deep fog (Odey 2015). So the political history of our dear country since 1960 is comparable to the story of a strong, wealthy and extravagant giant who suddenly became crippled, impoverished and beggarly at the peak of his fame. Fifty-seven years (57yrs) after independence, Nigerians have been reduced to the conditions of utter destitution by leaders who grab political power by hook and crook, and bestow on themselves boundless economic leverage, giving no consideration to the concept of the common good (Odey: 2015). Nigeria has become a metaphor in the game of paradox as it gives a picture of being a very rich and a very poor country at the same time. Current debates rest on the conclusion that Nigerian leadership suffers from extreme moral depravity and attitudinal debauchery (Agbor, 2011). In reaction, millions of Nigerians, particularly the young ones who feel that they are unjustly cheated and sidelined have some reservation against the nation. History has shown that no nation in the world grew and enjoyed steady development in almost all spheres of its national life without experiencing good and selfless leadership (Ogbeide, 2012). Regrettably, corruption has ravaged the country and destroyed most of what is held as cherished national values (Abah and Nwoba 2016).Achebe(1984) had posited "the trouble with Nigeria is simply and squarely a failure ofleadership". So, in all ramifications, our beloved country, the much vaunted giant of Africa, should do something urgently to better the lots of the citizens by ensuring improved economic base.

\section{STATEMENT OF THE PROBLEM.}

Nigeria's quandary, while scarcely exclusive within these developing countries is confidently exceptions in their space and tenacity. Widespread poverty, economic doldrums, pervasive corruption, political volatility, attenuated institution, societalstruggle are rife in many developing nations but Nigeria's situation 
might seem commonplace. In the last three decades, Nigeria, has made over \$ US 500 billion in oil exports, considerable quantity of which has periodically accumulated as revenue to the government at the centre though shared by the three tiers. It is astonishing that the country had lived through difficult and unfaltering economic deterioration since the oil wind fall few years back. Slothful growth and fast increasing population have generated intense surges in poverty. Nigeria's turmoil, pitiable governance, and economic decline cause the major challenges to sustainable development. In point of fact, economic disorder, fragile governance and communal polarity, make a characteristic of the social predicament at the epicenter of Nigeria's political economy. The failure of governance, a social disorder and economic retardation in Nigeria for years now is responsible for the way many foreign spectators and Nigerians regard the country as a failed state. Ogbu (2013) rightly observed that "what has been common over the years in our governance is the enthronement of clueless, parochial, attitudinal debauchery and uninspiring leaders, with attendant formulation of series of ill-informed and poorly implemented policies/civil service reforms which decapitated the service, leading to the exit of dedicated, competent bureaucrats and provided incentives for corruption. Nigeria elaborately exemplifies the challenges of improving governance and leadership, a virile and ever stronger free society and political democratization. Nigeria currently is experiencing a lot of challenges in all scopes of governance that is likely to be an obstacle to the realization of growth and development particularly at rural level. Ineffective leadership and corruption have impacted negatively on Nigeria's democratic stability and her economic development (Ebegbulem, 2012). Why, despite the establishment of anti-graft agencies, corruption still weakens institutions, discourages investment, and retards economic development? The aim of this paper isto investigate the parts of undemocratic practices, disgraceful leadership crisis and putridness that have played and are playing in creating dysfunctional governance in Nigeria,

\section{CONCEPTUAL CLEARIFICATIONS}

\section{Nigeria}

Nigeria is geographically located in Sub-Saharan Africa (West Africa) and is the most populous country in Africa and the eight in the world. Her population is about one hundred and seventy million people. It operates federal system of government, The Federal Republic of Nigeria is made up of six geographical zones; the south-south, south east, south west, north central, north west and north east. There is the central government and thirty six and federal capital territory, Abuja. Also, there are seven hundred and seventy four Local Governments Areas. The three tiers of governments are operated by elected group of persons charged with the responsibility of administration. On October 11960 Nigeria gained independence from Britain and self rule in 1963.

\section{Democracy}

Democracy continues to be the most popular form of government globally. Being a derivative of two Greek words meaning rule of the people, the central theme of the concept democracy is popular governance or ruler-ship of the people. Democracy represent a manifestation of a society where government is only one element co-existing in a societal fabric of many and varied institutions, political parties, organizations, and associations (Umar \& Tafida 2015). Pennock (1974:7) describes democracy as that government by the people, where liberty, equality and fraternity are secured to the greatest possible degree and in which capacities are developed to the utmost by means, including free and full discussion of common problems and interest. Democracy refers to "a set of ideas, institutions and processes of government that allows the broad mass of the people to choose their leaders and guarantees them a broad range of civil rights" (Ezeonu 2010;58). This is why imposition of candidates is undemocratic hence any true democracy should encourage social justice. For Schumetter and Karl (1991:76) democracy represent a modern political economy as a system of governance in which rulers are held accountable for their actions in the public realm by citizens acting indirectly through the competition and cooperation of their elected representatives. Answerability, integrity, pellucidity and limpidity in handling public affairs are the hallmark of democracy. For the purpose of this study, our interest is the notion of democracy concerned with the acceptable governance.

\section{Governance}

Governance is the way in which power is exercised in the management of a country's economic and social resources for development. The word governance originally derives from Greek verb 'kuBEpvaw", meaning to steer, demonstrated by Plato. Today governance is used to refer to the specific activity of ruling a country which is traceable to early modern England, when the phrase "governance of the realm"appears in works by William Tyndale (Wikipedia). The concept governance is often used holistically to depict situations in a nation showing the socio-economic development. Governance is "the process of decision -making and the process by which decisions are implemented (or not implemented). Good governance, on the hand is a concept that centers on the responsibility of governing bodies to meet the needs of the masses as opposed toselect groups 
in a society (Wikipedia). Effective administration is determined by the quest for the concern of the masses by those who manage or sees the nation's activities. The principles of democracy and good governance is often connected with the quick reactivity of state to issues and accountability to the people who gives the mandate to the leaders.There is no straight jacket definition of governance rather there are contextual meanings given depending on the circumstances. In a sovereign state like Nigeria governance is the legitimate power of those in power/leaders to govern the country. Therefore, the study argues that administrative malady and negligence of democratic principles contributes to a large extent the dysfunctional governance in Nigeria.

\section{THEORETICAL FRAMEWORK}

This study is anchored on two theories, the theory of the Classical Elite and the Anomic theory. In this study titled, "Nigerian Government Democracy and Dysfunctional Governance" the theory used was propounded by Vilfraedo Pareto (1848 - 1923) and Gaetano Mosca (1858 - 1941). Elite theory developed in part as a reaction to Marxism as an ideology rather than objective analysis of a social system. According to elite theory, men can never be liberated from the subjugation of an elite structure. Elite theory argues that all societies are divided into two main groups, the ruling minority and the majority that are ruled. These situations according to the theorists are inevitable. Public policies for instance are policies of every regime, made by few persons in government. The elite theory regards public policies as the values and preferences of the governing elite. In other words, public policies are the products of elites reflecting their values and serving their ends (Ibeogu: 2015). The political and economic elites wield powers, wealth, and influences government policies in their favour. The policies of the previous and present democratic government, Alhaji Tafawa Balewa/Dr Nnamdi Azikiwe (1960 - 1966), Alhaji Shehu Shagari (1979 - 1983), Chief Olusegun Obasanjo (1999 - 2007), Alhaji Umaru Musa Yar'dua (2007 - 2010), Dr Good luck Jonathan (2010 - 2015), General Mohammadu Buhari $(2015$ - 2017) was and is still also characterized by the struggle for who gets what, when and how of the proceeds of governance. Since the ruling minority constitutes the powerful in a given democratic system (godfathers and party stalwarts) who determines the place and fate of governance orchestrated by the politicization of government policies and programmes by the elites who influences the outcome, have given rise to the renewed insecurity, insurgency and political violence and failed economy in our democratic system.

On the second note, to ensure the relevance of this study, and correlate it with the objectives it intends to address, the anomic theory was adopted as another theoretical framework of analysis. The relationship between social class and crime in Nigeria is an issue that continues to attract attention from the media, policy makers and law enforcement agencies. The perpetrators of crime are economically disadvantaged and poor. Merton (1957) applied the concept of anomic to explain the causes of crime in a society. The word anomic, according to Durkheim is used to describe a social context in which the moral order has broken down for an individual or group, a situation in which social structural constraints of behavior become inoperative.

According to Durkheim (1938) an anomic society is one in which rules of behavior (norms) have broken down or become inoperative during the period of rapid social change or social crisis such as war or famine. An anomic society is not able to control human aspirations and demands. Anomic is most likely to occur in societies that are moving from mechanical to organic solidarity. Merton (1957) applied the ideas of Durkheim to criminology in his theory of anomie. Merton used a modified version of the concept of anomie to fit social, economic and cultural conditions found in modern U.S. society. He found that the two elements of culture interact to produce potentially anomic conditions, culturally defined goals and socially approved means for obtaining them. For example, Nigeria and some countries like U.S.A stresses the goals of acquiring wealth, success and power though through hard work, education and thrift. The illegitimate means are force and fraud because the social structure effectively limits the availability of legitimate institutionalized means: a strain is placed on people. Merton believed that strain could affect people in social classes but he acknowledged that it would most likely affect members of the lower class.

Merton (1957) argued that this feeling of norm-less arises when an individual is expected to achieve certain universal goals but does not have access to the appropriate means for achieving them. He considered material wealth a universal goal to which all aspire and the appropriate means of achieving wealth include; securing a good education and securing good jobs. When individuals do not have access to good education and jobs, Merton predicted that they might be tempted to obtain material wealth through inappropriate means such as criminal activity. Such individuals, not surprisingly would more likely come from the lower classes (Giddies and Duncer 2000) cited in Niyi, A (2014). This in the view of Merton was how kidnappers, insurgency, armed robbery, theft and other related crimes emerged in the country Nigeria.

\section{Nigeria and the Justice of Common Good}

The official document of the Catholic Church known as the Pastoral Constitution on the Church in the Modern World,defines common good as " the sum total of social conditions which allow people, either as groups or as individuals, to reach their fulfillment more fully and more easily". Putting more light on this 
definition, the document continues; "there is a growing awareness of the sublime dignity of the human person, who stands above all things and whose rights and duties are universal and inviolable. He ought, therefore, to have ready access to all that is necessary for living a genuinely human life: for example food, clothing, housing, the right freely to choose his state of life and set up a family, the right to education, work, to his good name, to respect, to proper knowledge, to safeguard his privacy and rightful freedom even in matters of religion. The social order and its development must constantly yield to the good of the person.It must be founded in truth, built on justice, and enlivened by love. Martin Luther King Junior who commented on what Beloved Community means as a result of the racial discrimination that triumphed in America, and all spheres of life. He said, "In a real sense, all life is interrelated. All men are caught in an inescapable network of mutuality, tied in a single garment of destiny. Whatever affects one directly affects all indirectly. I can never be what I ought to be until you are what you ought to be, and you can never be what you ought to be until I am what I ought to be. This is the interrelated structure of reality (Odey, 1999).

\section{The State of Governance in the States}

Every public officer is bestowed with trust, hence entail it is discharged with some level of honesty, probity, accountability and transparency. The former governor of Adamawa State and one time Chief of Naval Staff, was reported to have been impeached on $15^{\text {th }}$ July 2014 by the state legislature for an alleged gross misconduct and financial improprieties (Sunday Sun, $18^{\text {th }}$ July, 2014, Daily Independence, $17^{\text {th }}$ July 2014, Ibeogu, 2015). This is in contradiction to the oath of office he swore. He was alleged to have fraudulently mismanaged and diverted about fifteen billion naira ( $\$ 15 \mathrm{~b}$ ) belonging to the state. If it is true, then what becomes the faith of his subjects, as this money is meant to better the plights of the good people of Adamawa State by paying workers salary, providing and improving on the social infrastructure, such as roads, schools, hospitals, portable water etc. If the allegation was correct, then the impeachment should be justifiable, and then the accused should have been arrested by the law enforcement agency, interrogated, arraigned before the court of law, if found guilty, should be sent to jail as deterrent to other public office holders.

Bad or disgraceful as the actions of the former governor might be, he was rewarded handsomely, his eldest son, was elected a senator of the Federal Republic of Nigeria on $28^{\text {th }}$ March 2015. Pope Francis, talked about people who are pushed to the fringes of life and the way they ultimately react to their wretched condition, he was talking from experience. He came from the part of the world where millions of people live in abject poverty. He did not only see those living poor, he identifies with them, and so he clearly understands what effect of poverty could have on its victims (Advocate, 2015)

Nigeria is in a state of turmoil because a greater part of her children have been left on the fringes, this is because of the sufferings and pains they are going through. How long will it take the land to be in mourning as a result of pain and the death they are causing? How long will it take for the many other calamities they have brought to bear on our country in the name of leadership last? How long will it take the masses of this nation to cry out before they will hearken to their suffering by the leaders? How long will it take for providence to save Nigeria and Nigerians from the greed and the villainy of the hypocritical leaders who appear most virtuous at the moment when they are most vicious? When shall our leaders understand that they are primarily responsible for the violence, the insecurity and the blood that has been flowing in the land? Have they forgotten General Sani Abacha so soon? Have they forgotten that all the money he stole from the nations coffer did not save him and that it lost its value when he died? (Odey, 2015)

Recall that Umaru Musa Yar'dua and Dr Good luck Jonathan were sworn in as president and vice presidents on $29^{\text {th }}$ May 2007, but sequel to the death of Umaru Yar'dua on $5^{\text {th }}$ May 2010, and subsequent swearing in of Dr Jonathan as the president on $6^{\text {th }}$ May 2010. He emerged as the president of Nigeria in 2011 after the general elections, by March $28^{\text {th }} 2015$ after a keenly contested election, prior to his exit and subsequent handover; reports have it of a wide scale corruption in his administration especially in the petroleum sector. Worst still was non-payment of workers salary in most states of the federation after collecting their federal allocation. Such states include; Abia, Akwa-Ibom, Bauchi, Kogi, Benue, Cross Rivers, Ekiti, Imo, Jigawa, Kano, Katsina, Ogun, Ondo, Osun, Oyo, Plateau, Rivers and Zamfara owed their employees six months' salary arrears (Sunday Sun, $5^{\text {th }}$ March 2016). According to the report, while some states had paid salaries of workers up to date, some owed arrears of pensions running into months. The states owing salaries or pensions are Abia, Akwa-Ibom, Bauchi, Benue, Cross Rivers, Ekiti, Imo, Jigawa, Kano, Katsina, and Kogi. Others are Ogun, Ondo, Osun, Oyo, Plateau, Rivers, and Zamfara (Sunday Sun, $5^{\text {th }}$ March 2016). The report paints a bleak picture of civil service workers across the country. One terrifying issue about these crops of governors is that after collecting their share of the federation allocation which is meant for the payment of workers salary and upgrading of social infrastructure, such social benefits are denied. When these social benefits are denied and lacking, one organizing moment in our society is that these crop of leaders put up private schools, hospitals, industries and pay their private workers regularly (Ibeogu; 2015). Infact, since independence Nigerian 
governments especially at the state level is awash of naïve, narrow-minded, lackluster, attitudinal decadence and egotistic leaders.

Education: In his inaugural speech on May $29^{\text {th }} 1999$, the president lamented that military regime from whom he took over the leadership of the country allowed education and other social services to decay and collapse (Odey, 2000, Odey, 2004) eight years (8yrs) into Obasanjo's administration and ten years (10yrs) after Obasanjo's tenure, the various governments (administrations) instead of resuscitating the education sector that had decayed and collapsed, asphyxiated to death the educational institutions that were trying to survive (Odey, 2004). There is nothing wrong having private educational institutions side by side with the publicly owned, but what makes it worrisome and annoying is that these public officers failed to put public schools in good order while in office, but shortly after they left office, establish their own private education institution with modern facilities. For instance, while they were in office, the public schools were in dilapidated states, teachers (lecturers) hardly get their salaries, the school hardly open for academic programme (strikes) there were dearth of manpower, absence of I.C.T facilities, but all these are not lacking in their privately owned institutions of learning (Odey, 2004, cited in Ibeogu, 2015). These are what African leaders are known for, for instance, former prime minister of India, Rajiv Ghandi publicly stated that he believed $85 \%$ of government spending on development within India never reached its intended beneficiaries but was lost to corruption, while in Uganda, less than $30 \%$ of the funds dedicated to primary education was actually reaching schools in 1998 (Gentleman, 2006, Calderisi, 2006) in Uguru, 2014).

Health Services: Greater percentage of Nigerians cannot afford to foot the bills for whatever careless services our hospitals can provide under Nigerian government, the hospitals have graduated from mere consulting clinics they used to be to glorified patent medicine stores. In various regimes in Nigeria, provision of health services implies that if the wife of any of our leaders conceives here in Nigeria, she should go to the United State of America, France, Germany, or England to give birth to her baby to ensure safe delivery. It means that if any of our leaders have fever he should jump into the plane and rush to the United States of America, France, Germany or England for medical checkup. In Ebonyi State, the erstwhile government had to lease out the state teaching hospital (EBSUTH) to the federal government on the ground that the government had no money to pay the health workers their consolidated salary structure but high ranking government officials go abroad - India, Germany, U.S.A etc to access and improve their health condition, while the less privileged are allowed to die (Ibeogu, 2015).

Job Creation and Creation of Conducive Environment for Investment: The teaming youthful population in the country are turning into armed robbery, 419 fraudsters, kidnappers, prostitutions and engaging in all of criminality. Many of the questions the citizens bitterly ask God on daily basis is why he created them and put them here in Nigeria where the rich politicians and treasury looters are having blissful life. No state government makes establishment of industries a priority. The government total failure to create job for our youths have turned the whole country into an oasis of heinous crimes and insecurity of life and property, hence the polity is heated more than anything else and so becomes very difficult for the investors to come.

\section{Bitter evidence of dysfunctional Governance}

Abah and Nwoba (2016) lamented, "it is a bad scenario that Nigeria, the world's eighth largest exporter of crude oil, a country endowed with many natural resources, still has more than $70 \%$ its population living below the poverty line as a result of bad leadership.It was a moment of bitterness for civil and public servants in Ebonyi State on Monday $27^{\text {th }}$ July 2015. Sequel to the directive of the state government (governor) that all civil and public servants in the state should present themselves for personnel audit to enable the state ascertain the true staff strength of workers and come up with an acceptable wage package. The directives followed alleged wide allegations of the existence of "ghost workers" in the payroll of Ebonyi State Government. Recall that, the incumbent Leader had promised the workers of Ebonyi State who had embarked on strike for increase in salary on Monday $9^{\text {th }}$ March 2015 that he would effect one hundred percent (100\%) pay rise, if elected Governor. On Thursday $9^{\text {th }}$ April 2015, the former governor approved fifty percent $(50 \%)$ of the workers request with effect from $1^{\text {st }}$ February 2015. Hinging on those political promises, the workers massively voted for the Peoples Democratic Party's candidate. On assumption of office on $29^{\text {th }}$ May 2015, the new governor not only froze the account of local government but that salaries of local government were not paid for the month of May - July 2015 on the grounds of dwindling federal allocation, high level corruption and embezzlement of over one billion, eight hundred million (1.8b) in the local governments, and the presence of ghost workers in the public service, hence the directives of the personnel audit on the $27^{\text {th }}$ July 2015. Mathew Uguru Nkem (2015) reported of the workers protesting and demonstrating the non-payment of salaries in the streets of Abakaliki. In related development, Oginyi Nkechi and Nwigwe Ede (2015) reported of the collapse and death of one of the teachers 
in Ishielu local government area of Ebonyi State. The late public servant, aged 34yrs, was until his death, a teaching staff of Iduma Primary School, Ezillo, Ishielu Local Government Area. The said late staff was said to be hale and hearty when he left his family for the verification exercise as directed by the state government (Advocate, 2015)

Similarly, an orphan and a civil servant in Ebonyi State was reported to have stolen a goat used for offertory in one of the Catholic Parishes, in the Catholic Diocese of Abakaliki, Ebonyi State over the nonpayment of workers' salaries for months (Advocate, 2015).Furthermore, one of the reasons why the payment of salaries of workers was delayed for upward of three months, May -July 2015 by the governor was the decline in the federation allocation.

\section{Violence, Insurgency and Terrorism in Nigeria}

South-South Nigeria also known as the Niger Delta is of global interest for various reasons. It has one of the largest world's oil reserves in Africa. It is the engine room of Nigeria's economy because of foreign exchange earnings and revenue generation to the government. But the region has witnessed various forms of militancy, violent crimes (armed robbery) and kidnapping. The Niger Delta had for long been a place of serious contention between the state and various groups fighting for conscious environmental practice, resource control and development. The region suffered neglect despite various levels of agitation and protests by the people (Isaac Boro and Ken Saro Wiwa) during the military regime.

Townsend (2008) cited in Edwinah (2014) outlined that the root causes of rise in Kidnapping in Niger Delta Nigeria can be referred to as "natural resources nationalism", the tendency to seek bigger shares of the returns from natural resources. Edwinah (2014) traced the history and rise of kidnapping in South-South (Niger Delta) to the marginalization of the people of that region, the despoliation of the environment and the resultant conflicts have their roots in the discovery of oil as well as its exploration and production activities by the oil multinationals in the 1950's. Thegovernment of Nigeria has been compounding these problems through deliberate acts of oppressive policies (e.g. the controversial land use Act of 1978) and the persistent instances of marginalization in development (Akpan and Akpabio 2003, Onduku 2001) cited in Edwnah (2014).

Odey (2015) attributed the spate of violence, insurgency, terrorism, armed robbery and kidnapping to Niger Delta and other parts of Nigeria to government attitudes towards these regions as a reflection in the general absence of developmental attention as the people continue to live in pristine conditions and in cases without electricity, pipe borne water, hospitals, housing and schools, roads etc, in spite of the enormous wealth the government derives from the region. To add salt to injury, is the flagrant display of affluence in the country (Niger Delta) by foreign oil expatriates, Nigerian oil workers and government functionaries to the detriment of the people of the Niger Delta (Ibeogu:2015). Contributing further on the topic, Insurgency, Violence and Terrorism (Boko Haram) where is the hope of Nigeria?, Ibeogu (2015) stated that one of the fundamental duties or responsibilities of the state (government) is to ensure the security of lives and properties of its citizens, the protection of its territoriality and sovereignty and most importantly to guarantee it's socio - economic and political stability, but these responsibilities have been threatened by local and international terrorism and other related crimes. In Nigeria, the Boko Haram insurgency in the North-East States, especially with Yobe, and Borno State, and other neighbouring states have crippled governmental operations and state functions (Economic and administrative activities). A known case is the $25^{\text {th }}$ December 2011 bomb blast at St Theresa's Catholic Church in Madala, Niger State during a Christmas church service. Several lives, buildings, cars and other economic activities were lost during that inferno, till date, (2017) the consequences of that dastard act is still fresh in our memories especially with great economic loss in Borno State where the Igbo merchants are fleeing the state to where their business will be secure because of Bokoharam (Ibeogu, 2017). On Monday, April $14^{\text {th }} 2014$, it was reported that the Boko Haram sect kidnapped more than two hundred (200) girls from Government Girls Secondary School Chibok. Up to this hour and moment, the giant of Africa, (Nigeria) security operatives are unable to secure the release of these innocent girls, though about 21 girls were rescued in 2016, what about others? On Wednesday $25^{\text {th }}$ March 2015, it was reported that the dreaded sect (Boko - Haram) on $24^{\text {th }}$ March 2015, attacked Damasak, a town in Borno State, abducted five hundred and six (506) young women and children, but before fleeing with the abducted victims, about fifty (50) persons were killed.

\section{The Consequences of the Nefarious Activities of Violent Crimes in Nigeria's Economy}

Illiteracy, poverty, and greed can induce crime. This could be the philosophy behind the high scale of criminal activities across the country. In the Niger Delta (Akwa-Ibom State, River State, Bayelsa State, Delta State) etc, many years ago, crude oil was discovered in these areas of Nigeria. Multinational companies were invited to carry out exploration activities. In the process of exploration, economic activities of the area were affected; water pollution and degradation of the land. Expatriates and their Nigerian counterparts lived in affluence in the midst of the poor indigenes that are unemployed and lacked social facilities. The Niger Delta was neglected by oil producing companies, a situation compounded by the fact that the federal government 
lacked the policy framework for developing the region, inspite of the fact that crude oil is tapped in abundance in their locality. The situation created a class complex in which the expatriates are largely more economically endowed than their Nigerian counterparts. It was as a result of these, that some aggrieved youths of the Niger Delta came together as freedom fighters and started blowing up oil installations as a means of attracting the attention and patronage of oil producing companies and the federal government of Nigeria. When the strategy failed, it was changed to kidnapping of expatriate oil staff and Construction Company workers. Later, a new dimension was introduced to the crime, ransom was demanded, after due negotiation before the release of the kidnapped staff members. The youths saw kidnapping as a means to accomplish their goal of creating wealth since they lacked good education and cannot secure good jobs (Sunday Sun 2015, Odey 2015, Ibeogu, 2015).

In South East, criminal activities are not left out since the teaming graduates cannot access jobs anywhere, they have resorted to hostage taking and kidnapping. This unprecedented scenario have not only impaired negatively on the characters of the people (South-South and South East) but have paralyzed economic activities in the regions as investors no longer come to invest for the fear of being kidnapped. In the North, the economic effects of insurgency connote consequential effect on the people and the government. This is particularly with the residents of Yobe, Borno and neighbouring states. By their nature, it cripples economic activities of any town they attack, as well as lead to migration of people from the affected place (Edwinah, 2014, Odey, 2015, Ibeogu, 2015). People businesses have closed and this also led to the low level of patronage in the North. It has also gotten to a point that prospective corps members now reject posting for the mandatory one year youth services in the North, especially in states of Borno, Yobe, Bauchi, and Gombe etc. (The Nation, 2015, Sunday Sun 2015, Ibeogu, 2015).

Other known impact of violent crimes includes;

I. Dwindling Revenue Generation in the Revenue Potentials of Nigeria. The activities of these miscreants (kidnappers) forced the multinational companies to relocate to cities of Nigeria where their services are not required or return to their countries. The outcome is that since oil will no longer be explored in large quantities because of the decline of the oil explorers, the revenue base of the Nigeria economy will also be affected;

II. Loss of Jobs due to the Relocation of oil Companies. When the oil companies, relocates their services to other places or home countries, most employees in such companies are bound to lose their jobs especially the unskilled labourers. For example, Julius Berger Construction Company relocated from Port Harcourt cancelling their contract because of kidnapping of their workers. A good number of foreign workers relocated from the Niger Delta because of kidnapping. The few that were left were under tight security and jobs were lost because of the relocation;

III. Increase in the Cost of Providing Securities. Given the rise on the spate of armed robbery and kidnapping in Nigeria, a lot of security checks were introduced. More security personnel may have been employed that other businesses suffered losses. This is because more money was voted for security by individuals, groups, companies and government to the detriment of other economic sectors. Today, the only language we hear in the country from local government chairmen and state governors is that greater percentage of their federation allocation were used for providing security for harmonious existence (Ibeogu; 2015);

IV. Loss of Lives in the Hospitals due to the Abduction of Doctors. Cases of shutting down of hospitals (strikes by doctors) have been heard across the country for alleged kidnap of medical doctors. Sometime in 2014, a consultant with the federal teaching hospital (FETHA) Abakaliki, Ebonyi State, Nigeria was abducted. The Nigeria Medical Association (N.M.A) had to declare strike until he was released. During the period the strike lasted, patience could not access medical services in the government hospitals located in Abakaliki and so many lives were lost (Ibeogu: 2015);

V. Denial of Justice as a Result of Kidnapping Judicial Officers. In line with what happened in hospitals due to the kidnap of medical doctors, persons whose case are pending in law courts could not access the courts when some judges of Nigeria high courts and other categories of judicial officers were kidnapped. The judicial officers proceeds on strike and so those who were to access the court are meant to be remanded in prison custody.

\section{Outcomes}

The study established some of the factors that led to the undemocratic structure and gloomy socio-economic situation in Nigeria;

I. Corruption of the democratic and electoral system by the ruling class

II. Lack of internal democracy in political parties and imposition of candidates hence emergence of bad leaders

III. Grinding and growing poverty almost slipping into an absolute level

IV. A morose and leaky security situation resulting in malicious destruction of lives and property as seen in the North east Nigeria 
V. A crumbling health sector that merely provides medical and health consultation but make referrals to well established hospitals abroad thereby generating high rate of medical tourism which deplete our national reserve

VI. Insensitivity on the part of the executive arm by spending public funds on frivolities

VII. The economic system in place has been lurched to the depths by the continued looting of public treasury by public servants aided by their foreign cohorts and evil minded private sector agents

VIII. The legislative arm legalizing looting by budget padding and approving all the requests of the executive arm not minding its economic benefits or implications on the mass of Nigeria.

\section{CONCLUSION}

The study concludes that having investigated democratic failures, leadership cries and dysfunctional governance in Nigeria, it is crystal clear that these glitches have attained Olympian heights and contagion proportion especially since 1999 to the result of poor democratic governance in Nigeria is embodied as dysfunctional governance manifested in constant political crises, insecurity, abject poverty among the people, devastating fog of corruption and rising unemployment miseries. So to ensure a free, healthy, crime free society and robust economy, the government should live up to its electioneering promises.

\section{RECOMMENDATIONS}

The following recommendations were adduced for this study:

I. Elected representatives at all levels of governance should guarantee effective representations to the electorates as to ensure peace

II. The instant task of those entrusted with leadership should be to restore hope in governance. To yank the country from diving into the bottomless pit of a failed state

III. Enhance the quality of political leadership, allow openness and internal democracy, promote issue based politics, and gender friendliness among contesting candidates

IV. Legislative arm should not only avoid budget padding but deviate from conniving with the executive arm to legalize looting and cart away public fund

V. Accountability and transparency should be the articles of faith in the nation

VI. Leaders with vision should be elected or appointed

VII. Economic restructuring that will bring about improved living standards should be pursued

VIII. The leaders should lead with patriotism so as to take the country to the Promised Land as promised by the nationalist during their inaugural address on $1^{\text {st }}$ Oct. 1960

IX. The government should avoid spending public funds on frivolities

$X$. Reduce cost of governance because it increases expenditure, aggravates poverty, scares investors and reduces the credibility of the country's democratic institutions.

\section{REFERENCES}

[1] Abah, E.O and Nwoba, M.O.E (2016). Effects of leadership and Political Corruption on Achieving Sustainable Development: Evidence from Nigeria. Journal of Policy and Administration Research, 6 (6).

[2] Achebe, C. (1984). The Traceable with Nigeria. Enugu: fourth Dimension Publishers

[3] Adetutu, F. (2014) Intrigues of Nigerian Leaders over the peoples Affairs. Sunday Sun, $18^{\text {th }} \quad$ July 2014, $3-5$

[4] Agbor,U. I.(2011) Leadership attitude, development paradigms and African's fouth Republic. Journal of sustainable Development in Africa13 (1)

[5] Awoyinfa, S. (2015). Thugs Invade Tribwal, Beat up PDP Chiefs. The Nation, $13^{\text {th }}$ July 2015, 8 -9.

[6] A Communiqué Issued at the End of the Second Plenary Meeting of the Catholic Bishops Conference of Nigeria Held at Enugu on September $12^{\text {th }}-16^{\text {th }}, 1994$

[7] A Communiqué Issued at the End of the Second Plenary Meeting of the Catholic Bishops Conference of Nigeria Held at the Diocesan Catholic Secretariat, Uyo, Akwa - Ibom State, Nigeria, September $9^{\text {th }}-12^{\text {th }}$ 1997.

[8] A Communiqué Issued at the End of the Second Plenary Meeting of the Catholic Bishops Conference of Nigeria Held at St. Patrick Catholic Church Kpirikpiri Abakaliki Ebonyi State Nigeria. $11^{\text {th }}-15^{\text {th }}$ September 2011.

[9] Chinua, A. (1983).The Trouble with Nigeria. Enugu: Fourth Dimension Publishers.

[10] Oginyi, N. (2015) Government Directs Personnel Audit. Citizen Advocate St. Theresa's Cathedral Abakaliki. 11 (14), 15-17

[11] Ankpa, O (2014) Nigeria seek good governance.Daily Independence $17^{\text {th }}$ July, 2014, pp4-6.

[12] Edwinah, A and Udu, G (2014). Effects of Kidnapping on Business Operations in South Nigeria. Issues in Nigeria Public Policy Implementation: A Reader. Enugu. 
[13] Ebegbulem,J.C. (2012).Corruption and Leadership crisis Africa: Nigeria in Focus,International Journal of Businessand social science,3 (11) 221-227.

[14] George, E. (1996) A Prophetic Church (Ede: Provincial Pastoral Institute Publications,6

[15] Ibeogu, A .S and Nkwede, J. (2015).Political Violence and the Sustainability of Nigerian Democracy. Journal of Social Sciences Research, 8 (15) $17-23$.

[16] Ibeogu, A.S and Onwe, S.O. (2015) Party Impunity, Political Violence, and the Sustenance to Nigeria's Democracy: The Case of Ebonyi State, Nigeria. Unpublished Article Paper. Ebonyi State University, Abakaliki.

[17] Ibeogu, A.S and Nkwede, V.I. (2015).The Trouble with Governance and Performances of State Governors in Public Affairs: A Study of Selected States in Nigeria, 2007 - 2015. Unpublished Article Paper. Ebonyi State University, Abakaliki.

[18] Ibeogu, A.S.and Nwogbaga, D. (2015).Impeachment as a Crude Weapon to the Sustenance of Democracy: The Nigerian Experience. Unpublished Article Paper. Ebonyi State University, Abakaliki.

[19] Ibeogu, A.S and Onwe, S.O. (2015) the Impact of Insurgency on the Socio - Economic Development of Nigeria: The Case with Boko - Haram and Other Ethno Militia Organization. Unpublished Article, Ebonyi State University, Abakaliki.

[20] Ijewwereme, O. B. and Dunmade,E.O. (2014) Leadership Crisis and Corruption in Nigerian Public sector: Implications forsocio-Economic Development of Nigeria.International Journal of Public Administration and Management Research2(3). August 2014, retrieved on May 1, 2017.

[21] Ikejiaku,B. V.(2013)Political Corruption,a Critical Governance Problem Facing the Nigerian State;A comparative Assessment. A journal of African Policy Studies 16 (2).

[22] Ibeogu, A.S (2015) Assessment of Education Policies in Ebonyi State: The Case of Free and Compulsory Primary and Post Primary Education. A Ph.D Thesis Proposal.Presented To The Department of Public Administration, Ebonyi State University, Abakaliki.

[23] Madubuenyi, M. (2016). Woman's unpaid N285.00 bill. Sunday Sun, $5^{\text {th }}$ March, 2016, $3-4$.

[24] Merton, R. K. (1957). Social Theory and Social Structure. New York Free Press.

[25] Nigeria Labour Congress (NlC) Report on Employees Salary Across The Country, Nigeria.

[26] Nworie, A. (2015) To Pay Governors Wife N6M as W.D.C Boss. Citizens Advocate: St. Theresa Cathedral, August 2, 2015, II (32) 10 -13.

[27] Pennock, J. Roland (1979). Democratic Political Theory. Princeton University Press.

[28] Odey, J. (1999).Christians, Politics and the Nigerian Dilemma. Enugu: Snaap Press Ltd

[29] Odey, J. (2015).Who Made Kidnappers? Enugu: Snaap Press Limited.

[30] Odey, J. (2005).Democracy and theRipples of Executive Rascality. Enugu: Snaap Press Limited.

[31] Odey, J. (2004).The Children of a Wicked Generation, Why They are Angry, Desperate and Vicious. Enugu: Snaap Press Limited.

[32] Odey, J. (2000).The Parable of a Wasted Generation. Enugu: Snaap Press Ltd.

[33] Odey, J. (2005).The Lamentations of a Lost Generation, II. Enugu: Snaap Press Limited.

[34] Ogbeidi,M. (2012).Political Leadership and Corruption in Nigeria Since 1960:A soci-economic Analysis,Journal of Nigeria Studies, 1 (2) 1-25

[35] Ogbu,(2013).Making Political Leaders and civil servants work together,in L Ademolekun (ed)Higher Civil servants and their political Masters, Ibadan:colligate Publishing Company Limited.

[36] Oginyi, N and Nwigwe, E (2015) Verification Claims Teachers Life. Citizens Advocate, August 9, 2015, II (33).

[37] Onwe, S, Ibeogu, A and Nkwede, J (2015) Imperative of Legislative Oversight Function in Nigerian Democratic System. Research on Humanities and Social Sciences. 5 (4) $72-70$.

[38] Schmitter, P. C. \& Terry, L. K. (1991). What Democracy is and is not. Journal of Democracy 2 \# 3 (Summer). 75 -88.

[39] Umar, H. S. \& Tafida, A. D. (2015). Democracy and Social Welfare Services in Nigeria: A Perspective of the forth Republic. Journal of Public Policy and Administration Research. 5 (2), $59-65$.

[40] Uguru, M.N (2015) Man Caught With Offertory Goat. Citizen's Advocate, August 16, 2015, Vol 11 (15).Uguru, L and Ibeogu, A (2014) Effect of Bureaucratic Corruption and Lack of Public Accountability on Grass root Transformation in Nigeria. African Journal of Politics and Administrative Studies (AJPAS) 6(1) $106-115$ 